\title{
The Linguistic Concept «Russians Are a Fighting Nation» as a Tool to Manage Chinese Social Consciousness
}

\author{
Aleksandr N. Evdokimov and Dmitrii A. Savkin* \\ Baikal School of BRICS, Irkutsk National Research Technical University \\ Irkutsk, Russian Federation
}

Received 29.08.2021, received in revised form 02.09.2021, accepted 14.09.2021

\begin{abstract}
The study focuses on the concept of «Russians are a fighting nation» in the modern Chinese language, which emerged in 2013 and remains unknown to the vast majority of Russians. The concept has become a total synonym for the concept of «Russians» and has a positive connotation unusual for the Chinese language in the nomination of foreigners. The article is a comprehensive study of the «fighting nation» concept with consideration of its chronological, semantic and stylistic development as an instrument of influencing the worldview of the Chinese nation and the formation of its attitude towards other peoples. The study reveals that, initially, the concept of «the fighting nation» was artificially introduced and popularized by the Chinese authorities; then its internal structure was modified from the professional historical and cultural content to its further artificial transformation in 2016 into an Internet meme among the Chinese youth; and, finally, the loss of control over the dissemination of the concept led to the need for a campaign to discredit the «Russians are a fighting nation» concept, which has achieved only limited results. As a new and effective approach to managing the development of the concept, the Chinese authorities proposed to shift the positive features of the concept from the Russians to the Chinese and formulate a new postulate that «the Chinese are the real fighting nation», which has become the main development direction for the «fighting nation» concept for the next few years. The research findings can be applied in efficient international cultural communication, translation, as well as in a range of socio-cultural and linguistic studies.
\end{abstract}

Keywords: chinese language, mentality, concept, Russians, fighting nation, propaganda, lexical-semantic structure, connotation.

Research area: linguisctics.

Citation: Evdokimov, A.N., Savkin, D.A. (2021). The Linguistic Concept «Russians Are a Fighting Nation» as a Tool to Manage Chinese Social Consciousness. J. Sib. Fed. Univ. Humanit. soc. sci., 14(10), 1486-1498. DOI: 10.17516/1997-1370-0833

(C) Siberian Federal University. All rights reserved

* Corresponding author E-mail address: brics@istu.edu, iskander2@mail.ru 


\title{
Языковой концепт «русские - боевая нация» как инструмент управления китайским общественным сознанием
}

\author{
А.Н. Евдокимов, Д.А. Савкин \\ Иркутский национальный исследовательский технический университет \\ Российская Федерация, Иркутск
}

\begin{abstract}
Аннотация. В статье исследуется внезапно возникшее в китайском языке в начале XXI века и получившее широчайшее распространение в китайской языковой картине мира на всех языковых и социальных уровнях (за исключением официальной дипломатической риторики) устойчивое выражение «боевая нация» (кит. 战斗民族, zhàndòu mínzú), используемое исключительно для номинации жителей Российской Федерации и ставшее общепринятым синонимом к понятию «русские».

На основе изучения китайских и российских источников авторами исследуется диахроническое и синхроническое лексико-семантическое значение концепта «боевая нация», его коннотативные изменения, вызванные воздействием целого ряда внешних факторов: пропагандистская деятельность, форсирование и дискредитация концепта и т. д.; подробно анализируется структура концепта «боевая нация», с выделением центральных и периферийных компонентов; рассматриваются особенности функционирования концепта в среде современной китайской молодежи.
\end{abstract}

Ключевые слова: китайский язык, ментальность, концепт, русские, боевая нация, пропаганда, лексико-семантическая структура, коннотация.

Научная специальность: 10.02.00 - языкознание.

\section{Introduction}

Particular attention of the Russian philological community involved in the Russian-Chinese communication was drawn by the nomination of the Russian nation as «zhàndòu mínzú» (fighting nation) that emerged in recent years and widely spread in the Chinese media space (Baidu search returns 53.3 million versatile results, both serious and not, as of 04.2021) and in the Chinese linguistic and mental picture of the world. The uniqueness of this phenomenon lies, firstly, in the use of this expression as a total synonym applied exclusively to the concept of «Russians»; thus, Russians are the only nation that have recently received their own new fully functional name in the Chinese language; and, secondly, this nomination, according to all Chinese sources, has an entirely positive connotation: in the article «Fighting Nation (Russians)» in the Chinese online encyclopedia Baidu, it is emphasized that this is a comic expression in relation to Russians, which does not imply any humiliation or sarcasm (Fighting nation). Born in the Chinese linguistic consciousness and intended exclusively for internal use, the «fighting nation» concept remains unknown or unclear to the overwhelming majority of Russians; even specialists in Russian-Chinese relations do not always have a clear idea of the origin and meaning of this concept. For example, in an interview with the Russian state news agency RIA Novosti on October 02, 2019, Russian Ambassador to China Andrei Denisov said: «Let us have a look at how the Chinese perceive us, and how we perceive them. Of course, there are still a lot of problems here. I will mention at least one. In the Chinese press - probably, they did not come up with it themselves, but rather picked it up somewhere in the West-there is a discourse about Russians as a warlike nation or warlike people. And our Chinese friends - I have a lot of them here - in some normal conversations, they ask questions such as: Is it true that you 
are a warlike nation? And why is it so? I keep on explaining, relentlessly, that we are by no means warlike, rather the opposite; it just simply because of the whirling of our historical fate, we were in such conditions, at least in the last few centuries, that we constantly had to defend ourselves from someone ... We never attacked anyone, we did not start wars; instead, all kinds of dangers were constantly threatening us, and we had to defend ourselves. This is where, perhaps, this legend about us as some kind of warlike nation was born. This is what I tell our Chinese friends. This is but one example» (Andrei Denisov). It should be noted that, firstly, the West has nothing to do with the emergence of this concept in the Chinese language; secondly, the majority of Chinese specialists who speak Russian prefer to translate the expression «zhàndòu mínzú» into Russian as a «fighting» rather than «warlike nation», since the semantics of these definitions in Russian has a significant difference; and, thirdly, this name, possibly due to the use of the lexeme «warlike» in the translation, is perceived as somewhat unfair, offensive, and requiring explanations and even excuses.

\section{Statement of the problem}

At present, from the standpoint of effective international communication, it seems relevant to conduct a detailed comprehensive study of the «fighting nation» concept with due regard to its chronological and semantic development, namely:

1) to establish the time when it emerged;

2) to study modifications of its basic structure in the diachronic and synchronous aspects;

3) to single out the core and peripheral components of the concept;

4) to identify extralinguistic factors that had a direct impact on the formation of the concept;

5) to determine its impact on the mental picture of the world of the Chinese people;

6) and to clarify the semantic content of the concept at the time of the study.

\section{Methods}

The study used general research methods - comparative analysis, sampling method; general philological methods - contextological and conceptual analysis; as well as a specific philological method of semantic and stylistic analysis.

\section{The influence of Chinese culture \\ in the modern world}

With at least 5,000 years of history, as by far the majority of Chinese experts believe (or 3,500 years, as generally accepted in world science), the Chinese civilization is undoubtedly one of the most ancient and most important civilizations of our planet that have had an extremely important influence on the development of human history as a whole, and on the formation of our modern global multicultural community. It is difficult to overestimate the contribution of the Chinese civilization to the mankind's treasury of thought in science, technology, and humanities - including the four great inventions of the past (paper, typography, gunpowder, and compass); a tremendous corpus of philosophical, religious, and literary texts; actionable knowledge and skills in medicine and natural science, etc. Over the past decades, modern China has become one of the largest - and the largest in many industries - player on the political, economic, cultural and other arenas; it keeps on actively modernizing the face of our reality, offering the whole world the «new four great inventions of the Chinese civilization»: high-speed rail networks, e-commerce, mobile payment systems, and sharing economy. As we can see, unlike its previous forms, this iteration of the Chinese civilization is deeply integrated into the global structure and, as such, is no longer thought of apart from it. It is this massive impact on modern society and the leading position in many of its spheres that explains the keen interest in Chinese culture, mentality, philosophy, and science - an accurate and deep understanding of which is the key to successful, effective, and mutually beneficial communication between the Western and Eastern worlds. To achieve the goal mentioned above, it is particularly important to study the historical changes in the Chinese civilization that significantly or radically influenced the Chinese social consciousness, especially the Chinese cognitive and linguistic 
perception of other peoples who have been in contact with China in different periods.

\section{Two features of Chinese civilization \\ and their impact on the Chinese worldview}

Speaking of the Chinese civilization in general, we should mention its two unique features that define the Chinese mental picture of the world. First, it is cultural continuity throughout the history of the Chinese civilization: "China is almost the only country that gives an example of cultural development without radical destruction of the past in the name of the present» (Ezhov, 2004). Thus, many features of the Chinese mentality, psychology, and behavior determined in ancient times - for example, by philosophical views of great teachers of Taoism, Confucianism, Legalism, Buddhism, Mohism, natural philosophy, etc. - are fully present in modern Chinese consciousness, complementing and supporting the tenets of today's Chinese society expressed by the most prominent Chinese leaders and politicians of the second half of the 20th century- Mao Zedong, Deng Xiaoping, and Xi Jinping.

Secondly, the Chinese civilization was historically formed on a particular geographically isolated territory: from the west, the nascent civilization was protected by massifs of impassable mountains and deserts and, from the east and southeast, the Chinese lands were surrounded by the seas of the Pacific Ocean, while the northern and northeastern lands represented by endless steppes and forests with a harsh inhospitable climate, were, for a long time, of no interest to the Chinese nation - there were enough territories on the south. Thus, all the ecumene known to the ancient Chinese, suitable for normal life, was already Chinese (Ul'ianenko). Until the 19th century, in the absence of competition with a strong rival, the Chinese civilization and Chinese empire will be the undeniable historical and cultural hegemon in the region. Starting from the era of the first Chinese states, the Chinese mindset reveals the idea of "zhōngguó» - the Middle State as the unconditional center of the universe, extending its power and cultural influence over all known neighboring peoples who were, just like in other great civilizations, contemptuous- ly referred to as «barbarians», with a gradation from «semi-barbarians», i. e. those who were in the immediate sphere of Chinese influence, to «wild barbarians» - all other peoples. And «certain negative properties were attributed to barbarians: a barbarian was always an inferior person» (Smirnov, 2014). It was during the absolute domination of the Chinese state in all spheres over the neighbor countries and peoples that a clear sense of superiority was formed and consolidated in the Chinese mindset. It was a kind of «super-completeness»" complex, which can be described as extremely persistent Chinese chauvinism, as far as all the history known to the Chinese before the 19th century only testified to the fact that the Chinese way of life, the Chinese worldview and the Chinese civilization in general were the only true and progressive path of development. Moreover, all the failures along this path, for example, the conquest of the Chinese territory by the less developed, in all respects, nomadic tribes of the Jurchen, Mongols, Manchus, etc., were considered by the Chinese only as exceptions proving the rule, since the conquerors experienced the strongest assimilating influence of Chinese culture and turned into the Chinese.

A colossal blow to the Chinese sense of superiority over other peoples was inflicted in the 19th and the first half of the 20th centuries, when a powerful, technically well-developed and economically advanced, superior in all spheres Western civilization represented by the British, later the French, Germans, Americans, Russians, and the Japanese who adopted the Western civilizational model, reached the borders of the weakening Chinese empire. The Qing Empire could not challenge this pressure and admitted its complete defeat, which further led to the fall of the last Chinese dynasty. The occupation of Chinese territories, the defeat of the Chinese army and people's movements, the destruction of Chinese cultural sites, the extremely disdainful and even contemptuous attitude of the foreigners towards the Chinese population, towards the Chinese civilization itself, caused the Chinese nation to develop a persistent negative psychological fixation on these events, which continues to the present day. Particu- 
lar rejection was caused by the fact that the interventionists included Japan, which, in a couple of decades, transformed from a medieval state into a powerful and active capitalist predator. Despite the victory of China in the «1937-1945 war against the Japanese invaders», the self-esteem of the Chinese nation was impossible to recover, since the end point in Japan's surrender was set by the WWII allies: the defeat of the Manchu Japanese forces by the Soviet Union and atomic bombing of Japanese cities by the United States.

It was not until October 1, 1949, the day of establishment of the People's Republic of China, when Mao Zedong announced a special Chinese path of development, the Chinese nation began to gradually return to the centuriesold Chinese-centric worldview. The successes of the Chinese reforms led to the restoration of chauvinistic sentiments, and the undoubted triumph of China in the modern world in almost all spheres of life, especially in the demonstratively successful solution of global challenges (for example, against Covid-19), raised the degree of Chinese chauvinism to the previous, old imperial, level.

\section{Two mindsets}

\section{in the modern Chinese worldview}

The world picture of the modern Chinese nation reveals a serious conflict between two mindsets that directly determine the attitude of the Chinese towards other peoples: on the one hand, a clear sense of superiority (antiquity and modernity) and, on the other, a persistent psychological fixation on a particular historical period when everything Chinese was going down (the events of the 19th - first half of the 20th centuries). This antithesis naturally led to a situation where many widespread nominations of foreigners, in particular Russians, in the Chinese language have a clearly expressed negative connotation in their semantic structure, with the exception of the term "wàiguórén» ('foreigner') - an absolutely neutral one and therefore intensively promoted by Chinese authorities. All nominations that can be used in Chinese to designate Russians (without mentioning the country of origin) can be divided into three lexico-semantic groups:
1) nomination by features of appearance: «dàbízi» ('big-nosed', 'nosed' ones), «lăomáozi» ('hairy ones');

2) nomination by place of residence: «yángguǐzi» ('overseas devils');

3) nomination by behavioral characteristics: «lăowēi» (1. 'Foreigner'; 2. 'Profane, inexperienced, ignorant, clumsy').

While the negative connotation of the components of the first lexico-semantic group seems obvious, the nominations of the second and third groups require some explanation. The use of the expression «yángguǐzi» ('overseas devils') in relation to Russians was recorded in diaries of the famous Russian traveler N.M. Przhevalsky who explained this name by the poverty of the Chinese language and the lack of other possible options (Ul'ianenko). The thesis about the poverty of the nominative base of the Chinese language during the expeditions of N.M. Przhevalsky raises doubts: it is most likely that the Russians who arrived by land were called «overseas devils» simply by analogy with other foreigners who really all arrived from overseas - in this case, the key was the general meaning of «outlander».

As for the lexeme «lăowēi», there are conflicting viewpoints on its connotative completeness: Chinese linguists and philologists argue that this lexeme does not carry any negative assessment, while most international experts prove the presence of semes with negative connotation in the semantic structure of this word (Kisliuk). The author of the article adheres to the second point of view, because the presence of two lexemes («lăowèi» and «wàiguórén») - originating from the same language, with absolutely the same meaning, identical connotative coloring, with absolutely identical spheres of use and compatibility, on which the Chinese experts insist, - in active speech use for about 40 years contradicts one of the main tendencies of human language as a whole - the tendency to shorten the lexical vocabulary. In addition, the spheres of use of these lexemes still have a clear differentiation: "wàiguórén» is used in official communication, while «lăowēi» - in a low colloquial and vernacular style. 


\section{The emergence}

\section{of the «fighting nation» concept}

According to the Chinese search engine Baidu, the earliest reference to the "fighting nation» is in the article «The Pride of a Fighting Nation: Russia's T-90 Main Battle Tank» in the December 2013 issue of The Model World magazine (The pride of a fighting nation). This definition might have existed before, but was somehow limited in its distribution and range of use. Nevertheless, this expression began to spread, firstly, with a sharp deterioration in Chinese-American relations and, secondly, with the intensification of fruitful cooperation between China and Russia in all, including military, spheres. The South China: A Special View online edition explicitly states that «the 'fighting nation' meme was introduced by the Chinese propaganda as part of the image of the Russian-Chinese anti-American axis» (Veselovskii, 2019). This idea has a right to exist, based on a number of inferences and facts. First, as mentioned above, the basis of the Chinese attitude towards foreigners is the mental confrontation between two antithetic complexes superiority and inferiority. "China has drawn exhaustive conclusions from its thousand-year history, and especially bitter ones from the history of the 19th and 20th centuries. A rich culture, advanced scientific thought, national pride, ideology that unites the nation - all this can be useless in conflict with the outside world if you do not have sufficient economic power behind you» (Bavyrin, 2019). While the economy of the PRC provides the necessary level of security, successes in military affairs since the 19th century raise great doubts. In addition, since the Sino-Vietnamese war of 1979, the Chinese army has no longer participated in large-scale military operations, thus the real combat potential of the Chinese military forces are estimated very roughly, and this, again, makes the Chinese nation feel anxious based on negative examples from the past. At this moment, the Chinese people are offered a real «fighting nation» as their allies: "Russia is one of the three strongest world powers, especially because of its terrifying military power and vast territory, so no one can ignore it» (Sohu, 2019). Besides, it is Russia that is designated, in the Chinese publications, as the main opponent of the United States: "Russia is the main adversary of the United States. The United States, while remaining the hegemon, will definitely put pressure on Russia» (Sohu, 2019). Thus, according to D. Bavyrin, a columnist for the Vzglyad newspaper: "It is extremely naive to expect that China, in the foreseeable future, will get involved in some kind of geopolitical war with the United States. Quite the opposite, it will prefer to sit out, including behind the Russian back» (Bavyrin, 2019), which is fully consistent with both ancient Chinese stratagems and with the credo of the first chairman of the PRC Mao Zedong: "A wise monkey sits on a mountain and watches two tigers fighting in the valley» (Kortunov, 2020).

In the Chinese consciousness, the events of the «Crimean Spring» in 2014 have strengthened the idea of Russians as a «fighting nation» strongly defending its foreign policy interests not only through direct military conflict, but also capable of unexpected risky strategic and tactical decisions, challenging the existing world order and leading to an exponentially growing confrontation with the main opponents.

\section{First studies of the «fighting nation» concept in the Chinese linguistic environment}

By 2015, the phenomenon of the «fighting nation» has gained significant popularity in the Chinese language and has been widely spread in everyday discourse. The Chinese media make first attempts to analyze this concept, to identify its basic elements, and to explain them to a wider audience. For example, in October 2015, the 20th issue of the Chinese edition of World Vision under the heading with the notable title «Hot Spot», indicating the relevance of this publication, includes an article by Ma Yao, a special researcher from the School of International and Public Relations at the Shanghai International Studies University; the article «Why Russians are a 'Fighting Nation'?» contains professional in-depth research based on the historical and cultural materials (Ma, 2015).

The Chinese author identifies five elements that form the «fighting nation» concept: 
1. Vast territory conquered in the course of continuous military and economic expansion; it leads not only to the formation of a special national «temperament of extremes», but also instills a consciousness of the «great power", a sense of superiority over other peoples and the imposition of their own national interests. work in.

2. Cold climate difficult to live and

3. Continuous wars for survival and independence, which led to the complete subordination of the individual to the interests of the country, the introduction of a paramilitary and semi-nomadic system of life, as well as the ability to fight individually in complete isolation. All this ultimately led to the formation of a «strong military spirit» in the life of Russians: "The difficulties and hardships of Russia, as well as the hard and fierce struggle with nature and foreign conquerors had an extremely deep influence on the formation of the enormous military power, military strategy and unique military culture of Russia» (Ma, 2015).

4. The idea of «spiritual mission and salvation" of other peoples, introduced into the minds of Russians by the Orthodox Church, which has become an important ideological basis for expansion since the time of tsarist Russia.

5. A strong physique, great physical strength of the representatives of the Russian people, in which the blood of warlike Normans and Mongols is mixed: "We can say that a strong physique makes a "fighting nation» worthy of this name» (Ma, 2015).

It should be noted that the article is written in a friendly tone, the author really seeks to understand the origins of this concept, discussing with sympathy and understanding the peculiarities of Russian history and the life of the Russian nation, forming a positive connotation of the expression the "fighting nation" in Chinese readers as an ally of China in the possible confrontation with the United States: "The unique geographic environment, history full of conquest, social culture of fighting skills and strong physique made the "polar bears' famous for their bravery and courage. Recently, this "fighting nation» started a new battle by sending troops to Syria» (Ma, 2015). This quote contains another nomination of the Russian nation - «polar bears», which has a similar, albeit greatly simplified, semantic structure, also intended for internal use; development of this concept was brief, it thus never became so «memetic» in Chinese linguistic consciousness.

By 2016, the «fighting nation» concept under the influence of a targeted massive stream of Internet videos demonstrating very strange, unusual, bright, stupid, aggressive, and sometimes inadequate behavior of Russians, is undergoing a serious metamorphosis, suddenly becoming extremely popular among the Chinese youth. A number of events contributed to the popularity of this concept: TV series for young audience «How I Became Russian» - in Chinese the title is «How I Became a Fighting Nation»; the 2016 Soccer World Cup with fierce conflicts between Russian and British fans; and pilots of Russian airlines who made successful landings in the most difficult weather conditions, etc.

\section{The modern content}

\section{of the «fighting nation» concept}

In the Chinese social consciousness, the «fighting nation» concept has already acquired modern features. Its extreme popularity among Chinese youth is based on the principle of antithesis between the Russian and Chinese way of life, acting as a kind of very attractive «forbidden fruit»:

1. A particular type of personality of Russians: they are easily irritated and lose their temper, react to external actions as quickly and sharply as possible, often without taking into account the possible consequences. Chinese civilization cultivates a completely different type of personality and behavior: a deep reflection on the situation, taking into account the inevitable consequences, and exhibiting as little reaction as possible. The concern for the «keeping face» in any situation significantly limits the range of emotions displayed by the Chinese, and often forces them to suppress natural responses to stimuli. Thus, a Russian person, in the eyes of young Chinese, is much more free in the manifestation of his inner self. 
2. President V. Putin as a symbol of the «fighting nation»: a strong charismatic leader, ready to take risks and to confront the opponents. The popularity of the Russian president in China can hardly be overestimated; in many respects, it is built on the contrast with the image of the Chinese leaders. The effective work of the press center and the PR department have created a remarkable «heroic» image of the Russian president: extreme and combat sports, driving all types of vehicles, activity holidays in remote corners of Russia, information about household preferences, etc. - while little is revealed about the Chinese leaders, so they remain, as in older times, 'closed' persons for the Chinese masses. In the Chinese mental and linguistic picture of the world, the image of the «fighting nation's» leader is based on two programmatic statements, one of them belongs to the President of the Russian Federation: «We are going to pursue terrorists everywhere. If they are in the airport, we will pursue them in the airport. And if we capture them in the toilet, then we will waste them in the outhouse ... The issue has been resolved once and for all» (Putin). The other statement based on the ideas of P. A. Stolypin was attributed to V. Putin by the Chinese media: "Give me 20 years and I will give you a strong Russia!» (Russia, 2017).

3. The fearless treatment of dangerous wild animals by ordinary Russian people, in particular, with another generally recognized symbol of the Russian nation - the brown bear. It should be recalled that there are practically no large animals left in the wild in China, and an ordinary Chinese can meet a bear, tiger or wolf, etc. only in the zoo. That is why the behavior of Russians towards such extremely dangerous animals shocks the Chinese: «The bear is a very ferocious animal, but there are photographs on the web in which it seems that Russians mistake bears for pets, forcing them to do such things after which the bears lose their status of wild and dangerous beasts» (Russkie, 2018). All Chinese are well aware of the episode from the famous classic novel The River Creek, when the character Wu Song kills a ferocious tiger with his bare hands. After watching videos and photographs on the In- ternet on Russians and wild animals, Chinese youth come to the conclusion that the great deed of the Chinese literary hero does not seem to be anything special for the «fighting nation». Under the influence of the mental concept of the "fighting nation», a photo of Putin riding a bear (created in a photo editor) was perceived by a significant part of the Chinese public as a fact of reality. The difference in the attitude of Russians and Chinese to their national symbols is especially noticeable: the bamboo panda bear is positioned in modern Chinese culture as an absolutely peaceful, calm, and cute animal under state protection, enjoying the reverent respect and love of the entire Chinese people.

4. A Russian woman as a physically strong and morally independent person, ready at any time, if necessary, to challenge a man and end up winning, to solve any problem on her own. In traditional Chinese culture, even in our emancipated time, a different, albeit not always realistic, image of a woman is cultivated - gentle, sweet, weak, with no intentions to directly confront men.

5. Fearless Aeroflot pilots are the only ones who make successful landings in any, even extremely unfavorable weather conditions, while pilots from other countries are forced to change their route and go to airfields in other cities. Two Moscow-Beijing flights by the Russian airline Aeroflot appear as real examples in all sources: 1) October 2014, flight SU-200 - an hour and a half waiting in the air for the dispersion of thick fog in the sky over Beijing and a successful landing; 2) December 2016 - the only flight that landed in extremely bad weather conditions (strong wind and hail). On the Chinese Internet, very popular jokes are built in contrast to the usual behavior of the pilots of Chinese airlines: «Just getting on the plane of the "fighting nation", being two hours late with a flight and arriving an hour earlier is not a dream!» (Russia, 2017). Besides, the story of the famous American actor Leonardo DiCaprio on The Ellen DeGeneres Show about his worst moment in life - an Aeroflot flight, during which one of the aircraft's engines caught fire, and about the amazing calmness of the Russian crew and passengers (Russkie, 2018). 
6. «Vodka instead of blood»: a stereotypical view of Russians as people who barely get drunken even after drinking much. It should be noted that in Chinese culture, being on the street in a state of obvious alcoholic intoxication is strongly condemned and perceived as shameful.

7. Full adaptation to a cold climate and low temperatures - a stereotype based on a large stock of photo and video materials in the Chinese Internet, about the love of Russians of all ages, from kids to old people, for winter swimming, Epiphany bathing, and playing sports in the cold, working outside in low temperatures, etc. Although many Chinese live today in places with severe climate, the overwhelming majority of the PRC's population choose, as places of their residence, areas with a mild and temperate climate.

From 2016, all the Chinese media suddenly start referring to the Japanese comics manga «Dragon Ball», created by Akira Toriyama, and its numerous film adaptations very popular among modern Chinese teenagers, as to the origin of the concept of the "fighting nation». The humanoid alien race sayia-jin appears in the manga and TV series as the "fighting nation», and, although the manga was based on «Journey to the West» - classic Chinese novel popular in Japan, a number of specific characteristics of the Saiyan people made it possible to make a metaphorical transfer of the name the «fighting nation» to the representatives of the Russian nation: the Saiyan, like the Russians, 1) are a people with a culture alien to the Chinese; 2) have tremendous physical strength; 3) the harder they are beaten, the stronger they become in the end; and 4) because of constant wars, they are in a demographic hole.

\section{Campaign to discredit \\ the «fighting nation» concept \\ in the Chinese media}

Having compared the content of the «fighting nation» concept in the Chinese media in 2015 and 2016, we notice that there is a rapid change from a serious scientific approach to the study of the phenomenon, to its widest popularization as an Internet meme, which, in its turn, leads to a strong influence on the mind- set of Chinese youth. Chinese high school students start revealing the behavior traits related to the concept of the "fighting nation»: they address to each other using the Russian word «comrade»; they choose «Russian» kvass over more usual cola or milk tea; and, as a stylistic alternative to vodka inaccessible for them, they shout the Russian «hooray» at sports competitions, demonstrating solidarity and a high level of the «fighting spirit»; as well as all sporting successes of the students studying the Russian language are explained, in a half-joking manner, by the influence of the «fighting nation's» language.

Such popularity of the meme, as well as the vivid reaction of Chinese youth who truly admire and slightly envy Russians living a bright, free, albeit quite a peculiar life, was a complete surprise for the Chinese authorities. The reason is that, for the first time in many years, the younger generation chose as their «heroes» not the characters from the national history but the contemporary citizens of albeit friendly but, still, another country. In the fight to influence minds of their youth, Chinese authorities started discrediting the concept of Russians as the «fighting nation». The first step is, as noticed by all Russian-speaking users of the Chinese Internet, an increase in the flow of Internet materials with a clear negative content in relation to Russians: «These publications have a lot of video and photo materials where Russians engage in mass brawls, violate driving rules, play with weapons and drink liters of vodka. Rough humorous content, shocking and repulsive illustrations of Russian realities prevail. $<\ldots>$ all of this is drowning in an ocean of irony» (Karateeva), which now permeates each of the above elements of the concept of the " fighting nation».

In May 2016, Chinese Military Network (zhōngguó jūnwăng) - the military news portal of China, the only official Internet resource of the People's Liberation Army of China - published two articles that analyze how modern Russia and its people correlates with the concept of the «fighting nation». In the first article, «The unknown about Russia: is Russia really a 'fighting nation'», the authors openly admit that V. Putin never said the phrase «Give me 20 
years and I will give you a strong Russia!» and that the phrase was attributed to the Russian president by the Chinese media. The authors suggest the following: "Out of Putin's respect for Stolypin, combined with Putin's trajectory and thinking, it seems it is possible that Putin also has a «20-year complex» (Unknown about Russia), transparently hinting that neither P. Stolypin, nor V. Putin were able to radically transform Russia in 20 years. In addition, there is a noticeable decline in the Russian economy, and the attitude of the Chinese people towards the concept of a the «fighting nation» is characterized as a «blind worship of compatriots»: «It seems that only the Chinese speak this way,» said Sun Li Zhou, Deputy Dean of the Institute of World and Chinese Agenda at the Southwest University of Political Science and Law; he has visited Russia many times, communicated with Russians from different social strata and has never heard of Russians calling themselves «a fighting nation» (Unknown about Russia).

Second article (dated May 31, 2016), «A Different View of Russia Today», further discusses the issues the Russian economy is facing, noting that the stability of Russian society is based solely on the recently forced patriotism: "It is precisely because the Russian people are imbued with a trustworthy patriotic spirit that Russian society remains stable even under such economic pressure» (Inoi vzgliad na segodniashniuiu Rossiiu). In the second part of this article, «Is Russia a country of the 'fighting nation'?», the authors again criticize the enthusiastic reaction of the Chinese people, who do not understand the cultural differences between Russians and Chinese, and, after expressing several historical compliments to the Russian people, nevertheless declare that «it would be a mistake to label Russians as the «fighting nation» (Inoi vzgliad na segodniashniuiu Rossiiu). It should be noted that it is in this publication that the idea of a veiled transfer of the positive components of the «fighting nation» concept from the Russian to the Chinese people begins to manifest itself clearly. Thus, the authors of the article, characterizing the peculiarities of Russians as the «fighting nation», use the main ideas of modern Chinese propaganda about the Chinese people: «First, patriotism is deep in the people's consciousness; second, the people is against unceremonious encroachment on the interests of national survival; and, third, there is a strong sense of national pride. $<\ldots>$ true traits $<\ldots>$ of the "fighting people»: brave, but not fierce; able to fight, but not aggressive; strong, but not coerced by force» (Inoi vzgliad na segodniashniuiu Rossiiu).

The article «Four Weaknesses of Russia» by Sohu, Chinese media agency, reveals even harsher rhetoric. The article does not mention the «fighting nation» concept, but it still continues the campaign to debunk this concept, using a hidden comparison in favor of the PRC and the Chinese people.

1. Thus, analyzing the first problem of Russia - the demographic one, the authors of the publication note a huge disproportion between its female and male population. With the words of Mao Zedong, they deny Russia's status as the world power: «Mao Zedong once said: "The more people, the more strength.» $<\ldots>$ the population of 140 million people $<\ldots>$ does not suit to the status of the world power» (Sohu, 2019).

2. The second problem, according to the Chinese side, is the multi-nationality of the Russian state: «Russia is a multinational state. There are 194 nationalities in total, and Russians make up $80 \%$. This has created difficulties in leading the peoples inhabiting Russia; in other words, managing them is expensive» (Sohu, 2019); with 96 nationalities and $92 \%$ of the Han population, China seems to the authors a more stable formation.

3. Considering the third weakness - the economic one, the Chinese publication predicts a complete defeat for Russia on the world stage: «Today, in a global stabilizing situation when the economy is becoming more important, Russia with its weak economic development is doomed to failure» (Sohu, 2019), while the powerful economy of the PRC provides the necessary level of national security.

4. The fourth weakness is international relations, in which, as mentioned above, the Chinese authors assign Russia the position of the main enemy of the United States, and a lone enemy, since Russia does not have a single sig- 
nificant ally: the countries of Western Europe «experienced the horror of the Soviet period», the countries of Eastern Europe «were subjected to Russia's aggression», and the countries of the Middle East are dissatisfied with Russia.

Let us note that, summing up the results of the publication, the authors still call Russia the world power, but the content of the article itself directly contradicts this conclusion: in 2021, it is not China that needs Russia with its «fighting nation» as an allies, but Russia needs China as a strong ally to survive, with real military and economic power and numerous equally strong and militant Chinese people. The idea of transferring the content of the «fighting nation» concept to the Chinese people

The propaganda of «the Chinese are a real fighting nation» idea is actively and effectively carried out with the help of modern Chinese cinema and television: among the mass of inexpensive and uncomplicated film and television production, we note a number of highbudget ones produced recently and based on real events, albeit in a very embellished form, on military exploits, military skills, military spirit, patriotism, and self-sacrifice of Chinese soldiers of all eras, for example, Red Sea Operation (2018), The Eight Hundred (2020), Sacrifice (2020), etc.

It is likely that the impact of this idea manifests itself not only among ordinary citizens of the PRC, but also among the country's top leadership, representing China's interests in foreign policy. Thus, here is quite unexpected for the American side and the entire world diplomacy, instantaneous and extremely tough (which is absolutely not typical of the traditions of Chinese diplomacy) response of the Chinese delegation consisting of Foreign Minister and State Councilor Wang Yi and Director of the Central Commission on Foreign Affairs of the Chinese Communist Party Yang Jiechi to all the claims made by the United States during a bilateral meeting in Alaska on March 19, 2021: "Yang Jiechi: ... Therefore, let me say here that in the presence of the Chinese side, the United States has no right to declare that it is going to speak with China from a position of strength ... And even 20 or 30 years ago, the Amer- ican side did not have the right to say that, because it is impossible to do things with the Chinese people in such a way» (CNBC, 2021). Results

Taking into account the above facts, observations, and analysis findings, the author comes to the following conclusions:

1) with a high degree of probability, we can speak of not the natural linguistic development of the expression the «fighting nation» in relation to the Russian people, but of its artificial introduction and popularization at the initial stage in order to achieve certain political goals and the formation of mental attitudes of the Chinese nation towards Russians;

2) until 2016, the «fighting nation» concept had professional cultural and historical content and a clear positive connotation;

3 ) in 2016, the «fighting nation» concept undergoes a forced transformation into an Internet meme and is embedded as a constant in the modern worldview of the Chinese nation, mainly of the youth;

4) among the youth inclined to independently choosing an example to follow, the Chinese authorities lost, for some time, control over the functioning of the concept; this leads to taking measures against the popularity of the concept;

5) the campaign to discredit the concept of «Russians are a fighting nation», which has achieved only limited success, is an attempt to regain control over how the concept works and what it conveys;

6) a trend in this concept's development in the coming years is related to the transfer of positive features of the «fighting nation» from Russian to Chinese - an attractive thus efficient idea for the Chinese worldview.

Thus, after tracing the development of the linguistic concept of the «fighting nation» from its origin to the present, we have witnessed extensive transformations of the semantic structure of the concept, changes in its connotative assessment; we have examined its psychological impact on certain segments of the Chinese population, and also confirmed the possibility of using the "fighting nation» concept as a tool for influencing the Chinese social consciousness. 


\section{References}

Andrei Denisov: my s Kitaem ne soiuzniki, no ponimaem interesy drug druga [Andrey Denisov: we are not allies with China, but we understand each other's interests] (2020). Available at: https://ria. ru/20191002/1559312820.html (accessed on: 11 May 2021).

Bavyrin, D. (2019). Kitaitsy ne sluchaino nashli u Rossii «slabye mesta» [The Chinese did not accidentally find Russia's «weak points»], In Delovaya gazeta «Vzgliad» [Business newspaper «Vzglyad»]. Available at: https://vz.ru/politics/2019/11/19/1009031.html (accessed on: 11 May 2021).

CNBC (USA): osnovnye momenty zhestkogo dialoga mezhdu predstaviteliami SSHA $i$ Kitaia vo vremia vstrechi na Aliaske [Highlights of a tough dialogue between representatives of the United States and China during a meeting in Alaska] (2021). In ИноСМИ.RU. [InoSMI.RU]. Available at: https://inosmi.ru/ politic/20210320/249381776.html (accessed on: 11 May 2021).

Dragon Ball. Available at: https://en.wikipedia.org/wiki/Dragon_Ball\#Dragon_Ball_Z (accessed on: 11 May 2021).

Ezhov, V.V. (2004). Mify drevnego Kitaia [Myths of Ancient China]. Moscow, Izdatel'stvo Astrel, AST, 496 p.

Fighting nation. Available at: https://baike.baidu.com/item/战斗民族/15815792?fr=aladdin (accessed on: 11 May 2021).

Inoi vzgliad na segodniashniuiu Rossiiu [A different view of today's Russia]. Available at: https://www. facebook.com/notes/692363964993793/ (accessed on: 11 May 2021).

Karateeva, V. Pochemu kitaitsy schitaiut russkikh voinstvennoi natsiei [Why do the Chinese consider the Russians a militant nation?], In Magazeta [Magazeta]. Available at: https://magazeta.com/zhandouminzu/ (accessed on: 11 May 2021).

Kisliuk, L. Russkie glazami kitaitsev (vzgliad cherez ieroglificheskie ochki [Russians through the eyes of the Chinese (a look through hieroglyphic glasses)]. Available at: https://magazeta.com/e-russian/ (accessed on: 11 May 2021).

Kortunov, A. (2020). O mudroi obez'iane, spuskaiushcheisia s gory [About the wise monkey coming down from the mountain], In Rossiiskii sovet po mezhdunarodnym delam [The Russian Council for International Affairs] Available at: https://russiancouncil.ru/analytics-and-comments/analytics/o-mudroyobezyane-spuskayushcheysya-s-gory/?sphrase id=78104795 (accessed on: 11 May 2021).

Ma, Y. (2015). Why are Russians a «fighting nation»? In World Vision, 20. Available at: https://mp. weixin.qq.com/s?src=3\&timestamp=1620740986\&ver=1\&signature=LWLF6jTIAfYRU6QT8iRs11jBtuJRs5FffRpsgaFbVwIV-IHLErPm7vm-OpOdajfZ9HveWBiNrprdzkfNxLT7My0UjjHYiUsBdLOUyyRNn M4eQGZITPJcRYJwQCU7eXUb6TSUc9qKNUdQXWL0CR3udQ== (accessed on: 11 May 2021).

Putin, V. V. Available at: https://ru.wikiquote.org/wiki/Владимир_Владимирович_Путин (accessed on: 11 May 2021).

Russia: only the Chinese recognize the "fighting nation» (2017), In World Chinese Weekly. Available at: https://www.sohu.com/a/159383723_616577 (accessed on: 11 May 2021).

Russkie: my ne ponimaem, pochemu kitaitsy nazyvaiut nas «boevoi natsiei» [Russians: we don't understand why the Chinese call us a «fighting nation»] (2018). In InoSMI.RU [InoSMI.RU]. Available at: https://inosmi.ru/asviewedby/20180629/242611359.html (accessed on: 11 May 2021).

Smirnov, I.B. (2014). Nominatsiia inostrantsev i modeli obrazovaniia etnonimov v kitaiskom iazyke [Nomination of foreigners and models of formation of ethnonyms in the Chinese language]. Available at: https://urok.1sept.ru/articles/648002 (accessed on: 11 May 2021).

Sohu (Kitai): chetyre slabykh mesta Rossii [Sohu (China): four weak points of Russia], In InoSMI.RU [InoSMI.RU] (2019). Available at: https://inosmi.ru/social/20191117/246222749.html\#comments (accessed on: 11 May 2021).

The pride of a fighting nation. The Russian T-90 main battle tank. Available at: https://kns.cnki.net/kcms/ detail/detail.aspx dbcode $=$ CJFD $\&$ dbname $=$ CJFDLASN2014\&filename $=$ MXSJ201312006\&v $=$ UBU P6NZ9YhTplwLaHx6qwyjy4nc865VZ0XTAiaSFJHvLP\%25mmd2BlnaiQaOeE\%25mmd2FZnkg\%25mmd2FAe0 (accessed on: 11 May 2021). 
Ul'ianenko, V. V. Shokiruiushchie kitaitsy [Shocking Chinese]. Available at: https://mnogobook.ru/dokumentalnaya_literatura_main/publitsistika/352178/fulltext.htm (accessed on: 11 May 2021).

Unknown about Russia: Is Russia really a «fighting nation»? (2016). In iNEWS. Available at: http:// finance.ifeng.com/a/20160510/14374853_0.shtml (accessed on: 11 May 2021).

Veselovskii, N. (2019). Razvenchanie sily: agentstvo Sin'hua nazvalo mifom «boevuiu natsiiu» russkikh [Debunking the force: Xinhua news agency called the "fighting nation» of Russians a myth], In Uizhnyi kitai. Osobyi vzgliad [South China. A special opinion]. Available at: https://south-insight.com/ node/218200\#main-content (accessed on: 11 May 2021). 